\title{
The Global - Local Planes of English Needs in Indonesian Contexts
}

\author{
Christine Manara
}

Graduate School of Applied English Linguistics

Universitas Katolik Indonesia Atma Jaya

christine.manara@atmajaya.ac.id

DOI: https://doi.org/10.18326/rgt.v12i2.215-237

\begin{abstract}
Submission
Track:

ABSTRACT

Received:

$11-03-2019$

Final Revision:

21-11-2019

Available online:

01-12-2019

Corresponding

Author:

This article reports one part of a larger study on exploring the global and local English needs in nine secondary-level schools in several Indonesian regions (i.e. Sumatera, Sulawesi, and East Nusa Tenggara). The study investigates: 1) teachers' and students' perceived understanding of the existence of English in their local contexts; 2) opinions of their current local and global needs of English in today's globalized era; and 3) their opinions of the teaching and learning of English. Data were collected from questionnaires and interviews. The results show that students in different regions have slightly different views and perceptions of English use and how it needs to be learned and taught for their current and future needs for English. Although slightly different in their perceptions of needs, there

Name \& E-mail Address:

Christine Manara

christine.manara@atmajaya.ac.id seems to be a coordinated understanding of English needs between the students and teachers. The findings also indicate that there is a growing awareness of the need to teach the communicative aspects of English via online activities. Therefore, the teaching of English needs to be conducted by providing more English exposure, integrating blended learning, adopting the ESP approach (English for Specific Purposes), and teaching pragmatics knowledge and intercultural skills.
\end{abstract}

Keywords: Global and local English needs ESP Approach, Pragmatics knowledge, Intercultural Skills, ELT. 


\section{INTRODUCTION}

Globalization is the buzzword in the literature of English Language Teaching today. The existence of globalization can be immediately felt in many local contexts around the world. Along with globalization, English has often been given prestigious statuses, such as the language of globalization, prosperity, and modernity. Numbers of English learners and speakers are growing and have even outnumbered the Inner Circle countries (Crystal, 2003). The wider use of English as a Lingua Franca has also been perceived as one of what is considered to be $21^{\text {st }}$-century skills. Contrary to this positioning of English in the globalization flow, the allocated time for the English subject is reduced to 2 hours/week in the framework of Indonesia's current 2013 curriculum (often referred to as K13). This controversial decision of limiting English lessons to 2 hours/week was a result of a bipolar tug-of-war between the fear of English as a threat to Bahasa Indonesia (and local languages) and the needs of English as a lingua franca. Teachers are left alone with their judgment and available resources to fit themselves into the new policy.

This study was inspired by these dilemmatic conditions and perspectives in the teaching of English in Indonesia. It is specifically interested in investigating the local-global gravity force of the use, learning, and teaching of English in several Indonesian local contexts. This study particularly focuses on the high school level of education in several contexts in Indonesia. Therefore, this research is guided with the following research questions:

1. What are the Indonesian teachers' and students' perceived understanding of the existence of English in their local contexts?

2. What are the teachers' and students' opinions of their current local and global needs to teach and learn English in today's globalized era?

3. What are the teachers' and students' opinions on ways to teach and learn English?

\section{The making of English as the language of globalization}

The development of English language teaching has also responded to that of the status and roles of English from past to present. From the perspective of sociolinguistics, the positioning of language use and status in a particular context is always influenced by nonlinguistics factors (namely, power and ideology). Crystal (2003) mentions two major factors that contribute to the spread of English. In the beginning, it was the result of the expansion of British and American colonialism and the migration of English-speaking individuals to other 
areas in the world, which peaked towards the end of the $19^{\text {th }}$ Century. In relation to this, Phillipson (1990) coined the term "linguistic imperialism" in describing the early expansion of English as the language of colonialism through military, political, trading, and economic power of the British Empire during the colonialism era. He describes how English, at that time, was mandated to be used as the official language in the colonized countries. Some scholars (Canagarajah, 2005; Graddol, 1997, 2006; Phillipson, 1990) view this colonization act as the first wave of globalization that helped the spread of English to different parts of the world. By mandating English as the official language to be used in those countries, the language was taught to the locals to accommodate communicative purposes and other needs of the colonizer. The teaching of English is, therefore, orientating to the so-called "Standard English" as set by the colonizer. The development of English teaching methodologies and learning theories in the early years until the late 80s had drawn heavily from the perspective of English as the First Language acquisition for monolingual speakers, excluding the fact that bilingual speakers approach the acquisition of languages differently.

The second major factor is the emergence of the United States as the leading economic power of the twentieth century (Crystal, 2003). Globalization, at that time, was associated with the idea of westernization and 'Americanization' with the expansion of many leading American-based transnational corporations across the world establishing "global supply structures in mass market conditions" (Schneider, 2011, p. 52). Schneider (2011) describes that the wave of American cultural dominance was also brought by the media (through American TV series and Hollywood movies) as well as political influence.

Canagarajah (2006) adds that the advancement in digital technology and information has intensified the widespread of English in a very complex way. The rapid flow of information, languages, cultures, ideas, technology, and people has increased across borders, making languages, cultures, contact, and interaction a common phenomenon today. Along with this border-crossing phenomenon (physically and/or virtually), English has often been used as a Lingua Franca for intercultural communication in this globalization era. The users of English today are mostly bilingual (McKay, 2002). As a Lingua Franca, English is "far removed from its native speakers' linguacultural norms and identities" (Seidlhofer, 2001, p. 134). Additionally, English today has been used for utilitarian purposes (Feak, 2013) to serve local needs and functions. Therefore, the teaching of English grounded on native-speakerism ideology has been 
questioned since it is no longer relevant to the present time. The attention in English Language Teaching (ELT) has shifted from teaching learners to acquire English native-speaker competence to specific and contextual English communicational needs (Feak, 2013).

\section{English in 2013 National Curriculum (K13)}

The decision to have English as a Foreign Language within the National Curriculum dated back to the time following Indonesia's independence. Surviving the Dutch military aggression I and II (1945-1949), the government was able to reorganize the country's education sector in the early 1950s. During this time, as Buchori (2001) explained, the government felt the importance of acquiring another language for the country's international relations and encouraged the learning and acquisition of a Foreign Language. Due to the long Dutch colonization in Indonesia, the Dutch language was obviously not an option to be included in the country's language learning and acquisition planning. The government, then, turned to English as the preferred foreign language to be included in the National Curriculum. In the early 1950s, the Indonesian government approached the US and UK embassies for assistance in teacher education, which marked the beginning of a long history of, what Phillipson (1992) termed, the “English Language Teaching Aid” Programs in Indonesia (as cited in Manara, 2014b).

Within the National Education framework, English is still taught as a Foreign Language. It is a required subject to be learned at public and private schools all over Indonesia starting from grade 7 up to grade 12. English within the National Curriculum framework has been one of the main subjects tested in the National Exam (NE). However, for a subject that is being tested in the NE, English is only given 2 hours/week-now two hours short compared to the previous curriculum (KTSP). This decision seems to go against the reality today in which English, as Canagarajah (2005) explained, is being used as a medium for the locals to express their identity and culture to the global audience or participants.

The reduction of the time allocated for English in K13 has created a range of reactions and responses from teachers, parents, schools, and communities. To some parties, it is considered necessary to enhance the sense of nationalism. The argument is that Indonesian learners need to first be proficient users of Indonesian instead of other languages, and this can happen when Bahasa Indonensia is used from an early age in higher frequency and with maximum exposure at school. For this reason, English is considered to be a threat for the youngsters who are still learning and developing their Bahasa Indonesia. From this perspective, 
a direct link between language and the sense of nationalism is assumed. The learning of other languages at an early age may be considered a hurdle in the acquisition of the 'pure' First Language (L1) and First Culture (C1). Therefore, L1 learning needs to be treated in isolation with a high L1 exposure environment (closer to a monolingual environment, instead of a plurilingual one). The existence and use of other languages are seen as tainting the purity of L1 and $\mathrm{C} 1$ (hence, the sense of nationalism).

The other parties, however, question the idea of adopting this monolingual perspective towards language learning. They consider that minimizing English in a context with little and limited English speech domain means limiting the opportunity to English learning and use. In Indonesia, English use domains are mostly limited to schools (either learned as a subject lesson or used as the medium of instruction at some schools), transnational companies (mostly in big metropolitan cities), and tourism sites. Considering the scarcity of these English use domains in Indonesia, the decision of reducing English lessons to 2 hours is not accommodating the learning and acquisition of English, making it challenging for some teachers and schools to provide an English use environment during the lesson in the classroom.

To complicate matters, the contexts of English learning and use in Indonesia is also very diverse, ranging from schools located in areas with high access and exposure to English, wellestablished IT infrastructure, and tourism sites and schools located in rural areas with lower access and exposure to English. Some schools, especially private ones with high fees, offer an intensive English-speaking environment and treat English as a Second Language to be used at their schools (inside and outside the classroom). Other schools choose to apply two-hour English lessons in their classrooms whereas other ones experience teaching English as something so foreign to their immediate context (rural schools). Considering these different teaching conditions, English learning and teaching will certainly be perceived, valued, and approached differently. Knowing the diversity of contexts in Indonesia, this study is an attempt to explore the contextual needs of English use and learning in several Indonesian local contexts in today's globalized era as perceived by the local teachers and students. It is hoped that the information gained from this study will provide a contextual understanding of the interaction between local and global English communication. 


\section{RESEARCH METHODS}

This article is one part of a larger research project. The project adopts the mixedmethods research framework combining quantitative and qualitative approaches in its investigation. As explained by Hansen, Creswell, Clark, Petska \& Cresswell (2005), mixed methods "involve[s] the collection, analysis, and integration of quantitative and qualitative data in a single of multiphase study" (cited in Hesse-Biber, 2010, p. 3). The quantitative approach is adopted in the attempt of understanding the trends in English Language needs while the qualitative approach is adopted to gain specific information on particular aspects of the English language needs in the schools' context. Both quantitative and qualitative data are triangulated and worked to complement each other to gain better insights into the foci of the research.

The Quantitative research instrument used a questionnaire to survey the general trend in English competencies needed for English communication in today's globalized era. The questionnaire consists of two major sections that look at the current use of English in the participants' local context and the future use of English as well as the competencies that the students and teachers perceived as needed in the two settings (present and future use of English). To avoid any language barrier in filling out the questionnaire, the questionnaire is written in

\section{Bahasa Indonesia.}

The Qualitative research instruments used in-depth semi-structured interviews and classroom observation field notes. The interviews were adopted to gain a deeper understanding of the issues and concerns in teaching English in the globalized era. The interview participants were volunteers. Among the 32 teachers who filled out the questionnaire, nine teachers stated their willingness in the last section of the questionnaire to be interviewed and observed. The interview was conducted after the classroom lesson. For ease of communication, the interviews were conducted in Bahasa Indonesia. The interviews were audio-recorded and were approximately 40- 45 minutes long. A classroom observation scheme was also adopted as an instrument to record the teaching and learning activities of the participants. Due to conflicting schedules between the researcher and the teacher participants and limited available time of the teachers, classroom observation was only conducted once for each teacher. Most teacher participants had to attend to their additional responsibility of preparing third-year students for the National Exam (UN) after school hours. In trying to understand the contexts of each school, more background information on the school was sought out in the interview sessions. 


\section{Participants and settings}

A total of 18 participants of this study were recruited during the "English Teaching Assistant (ETA) and co-Teacher short enriching program" by the American Indonesian Exchange Foundation (AMINEF). ETA program is a 10-month program offered to American citizens to be English Teaching Assistants in schools in Indonesia (Lawson, 2018). In their fifth month, AMINEF holds a Mid-Year Enriching Program for both the ETAs and their co-Teachers (high school teachers). It is in this event that the researcher distributed the questionnaire to the co-Teachers. A consent form was also distributed and explained to the teacher participants. The explanations covered the participants' rights to participate and to withdraw from the research at any stage in the research process. A guarantee of anonymity was also explained to the teacher participants to protect the identity of the teacher participants. From 18 participants who fill out the questionnaire, nine participants agreed to be further interviewed and observed at their schools.

After requesting their permission, more questionnaires were distributed to their English colleagues (teachers) in their school. In total, 32 teachers and 248 students of nine Senior High schools in five provinces (i.e. North Sumatera, West Sumatera, East Nusa Tenggara, North Sulawesi, and Gorontalo) in Indonesia participated in this study. The types of schools visited were quite varied and unique with their particular characteristics, i.e. public school, private school, and boarding school (MAN). The demography and socio-economic contexts of the schools also range from urban to rural areas. Table 1 displays a brief profile of the nine schools visited, and Table 2 provides background information of the teacher participants being interviewed.

Table 1. Schools Profile

\begin{tabular}{|l|l|c|c|c|c|}
\hline School code & School Type & Location & $\begin{array}{c}\text { Teaching } \\
\text { context }\end{array}$ & $\begin{array}{c}\text { Exposure to } \\
\text { and use of } \\
\text { English }\end{array}$ \\
\hline 1 & School A (SA) & $\begin{array}{c}\text { SMA (Top Public } \\
\text { high school) }\end{array}$ & North Sulawesi & Rural & Very low \\
\hline
\end{tabular}




\begin{tabular}{|l|l|c|c|c|c|}
\hline 2 & School B (SB) & $\begin{array}{c}\text { MAN (Public } \\
\text { boarding school) }\end{array}$ & North Sulawesi & Rural & Very low \\
\hline 3 & School C (SC) & $\begin{array}{c}\text { SMA (Top } \\
\text { Private high } \\
\text { school) }\end{array}$ & North Sulawesi & Urban & Quite high \\
\hline 4 & School D (SD) & $\begin{array}{c}\text { SMA (Public } \\
\text { high school) }\end{array}$ & West Sumatera & Semi-Rural & Very low \\
\hline 5 & School E (SE) & $\begin{array}{c}\text { SMA (Top Public } \\
\text { high school) }\end{array}$ & West Sumatera & Semi-Rural & Very low \\
\hline 6 & School F (SF) & $\begin{array}{c}\text { SMA (Private } \\
\text { high school) }\end{array}$ & North Sumatera & Rural & Very low \\
\hline 7 & School G (SG) & $\begin{array}{c}\text { SMA (Top Public } \\
\text { school) }\end{array}$ & North Sumatera & Rural & Very low \\
\hline 8 & School H (SH) & $\begin{array}{c}\text { SMA (Private } \\
\text { high school) }\end{array}$ & $\begin{array}{c}\text { East Nusa } \\
\text { Tenggara }\end{array}$ & $\begin{array}{c}\text { Semi-Rural } \\
\text { (tourism site) }\end{array}$ & High exposure \\
\hline
\end{tabular}

Table 2. Interview Teacher Participants Profile

\begin{tabular}{|l|c|c|c|c|c|}
\hline Participant & Gender & School code & Qualifications & $\begin{array}{c}\text { Teaching } \\
\text { experience }\end{array}$ \\
\hline 1 & Eli & F & School A (SA) & MA-TEFL & $16 \mathrm{y}$ \\
\hline 2 & Nia & F & School B (SB) & BA-TEFL & $12 \mathrm{y}$ \\
\hline 3 & Ernest & M & School C (SC) & BA-English Lit & $9 \mathrm{y}$ \\
\hline 4 & Lea & F & School D (SD) & MA-TEFL & $14 \mathrm{y}$ \\
\hline 5 & Tini & F & School E (SE) & MA-TESOL & $21 \mathrm{y}$ \\
\hline 6 & Ari & M & School F (SF) & BA-TEFL & $6 \mathrm{y}$ \\
\hline 7 & Dita & F & School G (SG) & BA-TEFL & $14 \mathrm{y}$ \\
\hline 8 & Neli & F & School H (SH) & BA-TEFL & $10 \mathrm{y}$ \\
\hline 9 & Tomi & M & School I (SI) & BA-TEFL & $5 \mathrm{y}$ \\
\hline
\end{tabular}




\section{FINDINGS AND DISCUSSION}

\section{Students' and teachers' perceived opinions on English use in their local contexts}

One of the aims of this research is to investigate the students' and teachers' perceived opinions on English use in their local contexts. This data is obtained from the questionnaire (section 1). Despite the different teaching conditions, there are similar views among students and teachers across contexts. Table 3 displays the comparison of the average score of students' answers between those who live in the area with high (and active) exposure to English (SHEE) and those in the area with low exposure to English (SLEE).

Table 3. Students' opinions on English use in different local contexts (in average score)

\begin{tabular}{|l|c|c|}
\hline Q1. English in my local contexts is mostly used: & $\begin{array}{c}\text { High } \\
\text { exposure }\end{array}$ & $\begin{array}{c}\text { Low } \\
\text { exposure }\end{array}$ \\
\hline A. in education (learned as a subject matter) & 3.4 & 3.6 \\
\hline B. to upgrade someone's social status & 2.7 & 2.8 \\
\hline C. in economy & 3.0 & 3.0 \\
\hline D. in marketing (branding) & 2.8 & 2.8 \\
\hline E. as ELF between the local and international institutions & 3.2 & 3.0 \\
\hline F. in politics & 3.0 & 3.1 \\
\hline G. in social media & 3.3 & 3.2 \\
\hline H. for socio-cultural purposes to promote local cultures & 3.3 & 3.2 \\
\hline I. as professional English (language of profession) & 3.1 & 3.0 \\
\hline J. in intercultural communication with foreigners & 3.1 & 3.1 \\
\hline K. in tourism & 3.4 & 3.1 \\
\hline
\end{tabular}

There is a slight difference in the average score between SHEE and SLEE in item A (education), $E$ (ELF), and $K$ (tourism). Education sector receives the highest average score compared to other items in this section. This indicates that their real active encounter with and use of English is mostly at school during the English lesson rather than in other domains. For SHEE, the 
average score among the items is quite evenly spread out. The five domains that received a higher score as reported by SHEE are in education, in tourism, in politics, in social media, for socio-cultural purposes, and in intercultural communication and as the language of professional English. This is quite acceptable since SHEE has more opportunities and exposures to use English among these different contexts. Surprisingly, the average score of SLEE among the items is also evenly spread out just as SHEE. This may indicate that SLEE has the awareness of other English use beyond formal schooling, or at least their "imagined" (Anderson, 1983) use of English.

Interestingly, the average score of the teachers' answer is quite close to the students'. Table 4 shows the calculation of the average score of the teachers' response to questionnaire item 1.

Table 4. Teachers' opinions on English use in the local contexts (in average score)

\begin{tabular}{|l|c|}
\hline Teachers' opinions on English use in their local context & $\begin{array}{c}\text { Average } \\
\text { score }\end{array}$ \\
\hline A. in education (learned as a subject matter) & 3.4 \\
\hline B. to upgrade someone's social status & 2.8 \\
\hline C. in economy & 2.9 \\
\hline D. in marketing (branding) & 3 \\
\hline E. as ELF between the local and international institutions & 3.2 \\
\hline F. in politics & 3.1 \\
\hline G. in social media & 3 \\
\hline H. for socio-cultural purposes to promote local cultures & 3.4 \\
\hline I. as professional English (language of profession) & 3.3 \\
\hline J. in intercultural communication with foreigners & 3.3 \\
\hline K. in tourism & 3.2 \\
\hline
\end{tabular}

Five areas that obtained higher scores are English use in education, for socio-cultural purposes, as professional English, in intercultural communication, as ELF (local-international institutions), and in tourism. There seems to be a coordinated understanding between the 
teachers and students about the growing functions of English in other sectors although still limited in its use for most areas in Indonesia.

The highest score within this range of use was in the education field especially in the context of English lesson in class. This is a highly common response that the teachers shared in the interview sections, in particular, teachers who taught in the low English exposure area. This is best represented in Tini's account as follows,

[English is used] in education... but, in this context, English is not even used for communication in class. The teachers communicate or to teach English to the students using Indonesian. (Tini, 12/02/18)

Several teachers (Ernest, Tomi, and Neli) in high English exposure area (THEE) shared the immediate reality of English presence in their context and perceive English as the language of tourism and intercultural exchange. Tomi, a teacher at vocational high school (SMK), express his view on the role of English in his teaching context as follows:

Honestly, English is a basic need here. Aside from the fact that English is studied as a subject lesson here, and, well, since this town is a tourism site, English, for this young generation, becomes a medium to enter this industry [tourism]. So, the learning needs to be professional-based English learning. I'm talking about the context of vocational high school. It needs to be tailored to the needs in the field [of local tourism], but it doesn't mean that we need to ignore the curriculum's demands. So, I'm thinking of mixing the two because tourism atmosphere is strongly felt here.

In high English exposure areas where English is quite actively used, teachers have very high positive attitudes on English. These teachers assign additional values to English as the language of opportunity, prosperity, and international communication. Therefore, these teachers (Tomi, Ernest, and Neli) feel the need to teach intercultural skills side-by-side with the basic competence demanded by the National Curriculum. 


\section{Students' and teachers' opinions of their current local and global English needs}

Questionnaire item 2 aims to find out the students' and teachers' perceived current needs of English in their local context. In this section, there is a significant difference in the average score between SHEE and SLEE answers as displayed in table 5.

Table 5. Students' opinions on their current English use in different local contexts (in average score)

\begin{tabular}{|l|c|c|}
\hline Q.2. My current English needs & $\begin{array}{c}\text { High } \\
\text { exposure }\end{array}$ & $\begin{array}{c}\text { Low } \\
\text { exposure }\end{array}$ \\
\hline a. to pass National Exam & 2.5 & 3.3 \\
\hline b. to study other subjects & 3.1 & 3.2 \\
\hline c. to participate in academic activities outside of school & 3.1 & 3.1 \\
\hline d. to speak out my voice at social media & 2.7 & 2.7 \\
\hline $\begin{array}{l}\text { e. to participate in international academic discussion } \\
\text { through the Internet }\end{array}$ & 3.0 & 3.1 \\
\hline $\begin{array}{l}\text { f. to introduce local culture internationally through social } \\
\text { media }\end{array}$ & 3.3 & 3.2 \\
\hline g. to enjoy other foreign cultures through the Internet & 2.9 & 2.9 \\
\hline $\begin{array}{l}\text { h. to socialize with other foreign speakers of English } \\
\text { through the Internet }\end{array}$ & 3.2 & 3.2 \\
\hline
\end{tabular}

It can be seen from the table that SLEE reported higher urgency in learning English to pass the standardized National Exam (Ujian Nasional) than SHEE. This result supports SLEE perceived view (from questionnaire item 1) that English is mostly felt in the education sector and learned as a subject lesson at school. For other items of Question 2, the average scores are quite similar in nature. There is a slightly higher score result for SLEE for item B, E, and F compared to the SHEE result. This may indicate that students feel the importance of English for the purposes of studying other subjects, participating in international academic discussion, and introducing local culture internationally through social media through the medium of the Internet.

When asked to rank the language skills and knowledge that they urgently need in the order of importance, both SHEE and SLEE still rank basic language skills, vocabulary, and 
grammar knowledge as the five important skills. Table 6 shows both groups perceived language skills and knowledge of their current needs.

Table 6. Rank of English skills and knowledge for students' current needs

\begin{tabular}{|l|c|c|}
\hline $\begin{array}{l}\text { Q.3. Rank the language skills \& knowledge that you } \\
\text { need right now based on the order of importance } \\
(1=\text { most important to 9 = least important })\end{array}$ & $\begin{array}{c}\text { High } \\
\text { exposur } \\
\text { e }\end{array}$ & $\begin{array}{c}\text { Low } \\
\text { exposure }\end{array}$ \\
\hline Reading & 4 & 2 \\
\hline Writing & 5 & 1 \\
\hline Speaking-Listening & 1 & 3 \\
\hline Grammar & 3 & 4 \\
\hline Vocabulary & 2 & 5 \\
\hline Communication Strategies & 6 & 6 \\
\hline Pragmatics & 7 & 7 \\
\hline Intercultural Communication skill & 8 & 8 \\
\hline Transfer skill & 9 & 9 \\
\hline
\end{tabular}

The result may not be a surprising result since these language skills and knowledge (grammar and vocabulary) have been given so much attention in the National Curriculum that they experienced since grade 7. It is, therefore, quite understandable that communication strategies, pragmatics knowledge, intercultural communication skill, and transfer skill are less recognized by both groups.

Comparing the result of both groups, it can be seen in table 4 that writing and reading are placed to be the two most important skills to be learned by SLEE group. This result is in line with their reported urgent need for passing the National Exam that tends to test their reading and writing skills. SHEE, however, place speaking-listening skill and vocabulary as the two most important learning skills to be learned for their current English needs. The focus on vocabulary and spoken production skill can be related to the two highest scores on Question 2 (see Table 3): to introduce local culture internationally through social media (item $2 \mathrm{~F}$ ) and to socialize with other foreign speakers of English through the Internet $(2 \mathrm{H})$. The connection 
seems reasonable since these two language aspects are needed to serve the purpose of social communication through social media on the Internet that is interactional by nature.

Teachers, however, have quite different perceptions of the students' current English needs. The average score of the teachers' response on the questionnaire shows that the students heavily need English for their virtual activities through the Internet (item F, G, and H) as shown in table 7.

Table 7. Teachers' opinions on their students' current English needs

\begin{tabular}{|l|c|}
\hline My students' current English needs & $\begin{array}{c}\text { Average } \\
\text { score }\end{array}$ \\
\hline a. to pass National Exam & 3 \\
\hline b. to study other subjects & 2.9 \\
\hline c. to participate in academic activities outside of school & 2.8 \\
\hline d. to speak out my voice at social media & 2.7 \\
\hline $\begin{array}{l}\text { e. to participate in international academic discussion } \\
\text { through the Internet }\end{array}$ & 2.8 \\
\hline $\begin{array}{l}\text { f. to introduce local culture internationally through social } \\
\text { media }\end{array}$ & 3.2 \\
\hline g. to enjoy other foreign cultures through the Internet & 3.2 \\
\hline $\begin{array}{l}\text { h. to socialize with other foreign speakers of English } \\
\text { through the Internet }\end{array}$ & 3.3 \\
\hline
\end{tabular}

The teachers believe that their students spend more time on the Internet rather than in real life studying at school or at home. Therefore, they view that item F, G, and $\mathrm{H}$ are more relevant and realistic needs for the students today. Students interact more online rather than face-to-face interaction. This is quite a common theme that the teachers shared during the interview. This belief is best depicted by Eli's account in which she compared her time as a student with her current students' life.

...if I looked back to my time as a student, I studied English just to be able to answers the questions of the test in English lesson. But, today's generation, they are so curious about everything they see and find on the Internet, or even the apps they use on the Internet. All are in English. (08/02/18) 


\section{Students' and teachers' opinions of their future local and global English needs}

To understand students' attitudes towards English learning, the questionnaire also seeks information on students' opinions of their near future needs of English. Table 8 shows the average score of students' responses.

Table 8. Students' opinions on their future English use in different local contexts (in average score)

\begin{tabular}{|l|c|c|}
\hline Q.4. My future English needs & $\begin{array}{c}\text { High } \\
\text { exposure }\end{array}$ & $\begin{array}{c}\text { Low } \\
\text { exposure }\end{array}$ \\
\hline $\begin{array}{l}\text { a. to participate in academic activities in local/national } \\
\text { university }\end{array}$ & 3.3 & 3.5 \\
\hline $\begin{array}{l}\text { b. to study abroad at countries that use English as the First } \\
\text { Language (e.g. USA, UK, Australia, etc.) }\end{array}$ & 3.3 & 3.5 \\
\hline $\begin{array}{l}\text { c. to study abroad in other countries that use English as a } \\
\text { Lingua Franca (e.g. Thailand, Singapore, German, etc.) }\end{array}$ & 3.2 & 3.3 \\
\hline $\begin{array}{l}\text { d. to work abroad in countries that use English as the First } \\
\text { Language (e.g. USA, UK, Australia, etc.) }\end{array}$ & 3.1 & 3.4 \\
\hline $\begin{array}{l}\text { e. to work abroad at other countries that use English as a } \\
\text { Lingua Franca (e.g. Thailand, Singapore, German, etc.) }\end{array}$ & 3.1 & 3.3 \\
\hline f. to work in transnational companies in my local area & 3.1 & 3.3 \\
\hline g.to enjoy foreign products and culture & 3.0 & 3.0 \\
\hline h. to create and promote local culture internationally & 3.1 & 3.3 \\
\hline
\end{tabular}

Surprisingly, SLEE gives a slightly higher score in almost all the categories compared to SHEE score. The three categories that received the highest score by SLEE are to participate in academic activities in local/national university (item A), to study (item B) and to work (item D) abroad at countries that use English as the First Language (item B). SLEE projection of their future English need to participate in the local/national university may indicate their awareness that English has been one of the basic requirements for university entrance and that they will still have to learn English in the university level. Item B and D may indicate SLEE long term desire to use English for studying or work abroad particularly in the so-called inner circle 
countries. It may also indicate their high exposure to English which they perceived as coming from the inner circle countries.

For SHEE, three categories that received the highest score are almost similar to SLEE. These categories are to participate in academic activities in local/national university (item A), to study abroad at inner circle countries (item B), and to study abroad at other countries that use English as a Lingua Franca (item C). The focus is more on continuing further education either in or out of the country. There is no specific preference of either being in an inner or outer circle abroad.

As regards their future English needs, students were asked to rank the language skills and knowledge that they would need to acquire in the near future. Interestingly, there is a slight change in priorities that the students set for their future English needs. This shift of priorities can be seen in Table 9 .

Table 9. Rank of English skills and knowledge for students' future needs

\begin{tabular}{|l|c|c|}
\hline $\begin{array}{l}\text { Q.5. Rank the language skills \& knowledge that you } \\
\text { need in the near future based on the order of } \\
\text { importance (1 = most important to 9 = least important) }\end{array}$ & $\begin{array}{c}\text { High } \\
\text { exposure }\end{array}$ & $\begin{array}{c}\text { Low } \\
\text { exposure }\end{array}$ \\
\hline Reading & 4 & 2 \\
\hline Writing & 6 & 6 \\
\hline Speaking Listening & 1 & 1 \\
\hline Grammar & 3 & 4 \\
\hline Vocabulary & 2 & 3 \\
\hline Com. Strategies & 5 & 5 \\
\hline Pragmatics & 7 & 7 \\
\hline ICC & 8 & 8 \\
\hline Transfer skill & 9 & 9 \\
\hline
\end{tabular}

In the previous section (Table 6), both SHEE and SLEE reported higher priorities in learning the five basic skills and knowledge (grammar and vocabulary). In table 9, it can be seen that "writing" has been pushed down by "communication strategies". This is an extreme shift reported by SLEE group that voted writing at the first place in their current English skill need, and now being placed on the sixth place for their future English need. SLEE score shows that 
"speaking-listening" skill was given the first priority. There is also an interest in including communication strategies in their main five categories.

Although the ranking order of current and future English needs does not change that much for SHEE, there is a similar tendency as SLEE for preferring communication strategies to writing skills. In the current English needs section, writing was previously put in fifth place and now it is being placed in the sixth-placed. There seems to be a growing awareness in the two groups of the communication function of English today and in the future requires the knowledge of communication strategies.

Different from the students' view of their future English needs, teachers assigned a quite different projection of needs. Table 10 shows teachers' view on their students' future English needs.

Table 10. Teachers' view on their students' future English needs

\begin{tabular}{|l|c|}
\hline My students' future English needs & $\begin{array}{c}\text { Average } \\
\text { score }\end{array}$ \\
\hline $\begin{array}{l}\text { a. to participate in academic activities in local/national } \\
\text { university }\end{array}$ & 2.9 \\
\hline $\begin{array}{l}\text { b. to study abroad at countries that use English as the First } \\
\text { Language (e.g. USA, UK, Australia, etc.) }\end{array}$ & 3.1 \\
\hline $\begin{array}{l}\text { c. to study abroad at other countries that use English as a } \\
\text { Lingua Franca (e.g. Thailand, Singapore, German, et.c.) }\end{array}$ & 3.1 \\
\hline $\begin{array}{l}\text { d. to work abroad in countries that use English as the First } \\
\text { Language (e.g. USA, UK, Australia, etc.) }\end{array}$ & 3.1 \\
\hline $\begin{array}{l}\text { e. to work abroad at other countries that use English as a } \\
\text { Lingua Franca (e.g. Thailand, Singapore, German, et.c.) }\end{array}$ & 3.1 \\
\hline f. to work in transnational companies in my local area & 3 \\
\hline g.to enjoy foreign products and culture & 3.1 \\
\hline h. to create and promote local culture internationally & \\
\hline
\end{tabular}

The average score of the teachers' response shows almost equal attention to the different use of English. Most future English situations that the teachers imagined are related to the use of English (for studying and working) abroad. This is understandable since English has no official 
status in Indonesia and that its intensive use is mostly found in the context of English being taught as a lesson in class. There is still very limited domains of use for English in Indonesia. Even in the big cities like Jakarta and Surabaya, the domain use of English exists mostly in transnational companies or in international transactions through the media of Internet, and bilingual schools (as the language of instructions and language of socialization at schools among the students).

\section{Students' preferred learning style and teachers' opinions on English teaching methodology}

Based on the students' reported view on their future English needs, the students were asked about their preferred English learning style to accommodate their needs. Table 11 provides the details of the questionnaire items with the students' response average score.

Table 11. Students' preferred learning style

\begin{tabular}{|l|c|c|}
\hline My learning methodology & $\begin{array}{c}\text { High } \\
\text { exposure }\end{array}$ & $\begin{array}{c}\text { Low } \\
\text { exposure }\end{array}$ \\
\hline a. taking extra English lesson outside of school & 3.2 & 3.2 \\
\hline b. taking English lesson online & 2.9 & 3 \\
\hline c. joining an English-speaking community & 3.3 & 3.1 \\
\hline d. using English with friends or family members & 3.2 & 2.9 \\
\hline e. reading English texts or news online & 3.2 & 3 \\
\hline f. listening to English songs and watch English movies & 3.5 & 3.3 \\
\hline g. using English applications on my mobile phone & 3.3 & 3.1 \\
\hline h. making friends with foreigners through the Internet & 3.2 & 3.1 \\
\hline i. writing a journal or diary in English & 2.9 & 2.7 \\
\hline j. writing a blog in English & 2.7 & 2.8 \\
\hline
\end{tabular}

The preferred learning styles that received a higher score by SHEE and SLEE are almost similar in range. Both groups seem to agree that exposure to English is very important that both groups preferred learning through pop culture (listening to English songs and watch English movies) 
more than the others. Both groups also seem to agree that learning English at school is not enough for their needs and that both reported the need to take extra English lesson outside of school. Other traces of exposing themselves with more English can be seen from their preferences of wanting to use English apps on mobile phone, join an English speaking community, read English texts or news online, and make friends with foreigners through the Internet. These activities are in line with what the teachers pointed out during the interview in which students today has depended so much on IT advancement in most of their daily activities. These teachers' observation can actually be captured from their reported opinions on how English teaching needs to be learned and taught in the following paragraph.

In finding out the teachers' understanding between the needs and ways of teaching English, the questionnaire also asks teachers to give their opinions on ways to approach the teaching and learning of English. Table 12 lists the average score on teachers' approach to the teaching of English.

Table 12. Teacher's opinions on English teaching methodology

\begin{tabular}{|l|c|c|c|c|c|}
\hline English Teaching Methodology & $\begin{array}{c}\text { strongly } \\
\text { agree }\end{array}$ & $\begin{array}{c}\text { agre } \\
\text { e }\end{array}$ & $\begin{array}{c}\text { disagre } \\
\text { e }\end{array}$ & $\begin{array}{c}\text { strongly } \\
\text { disagre } \\
\text { e }\end{array}$ & $\begin{array}{c}\text { Averag } \\
\text { e score }\end{array}$ \\
\hline $\begin{array}{l}\text { a. English should be learned since } \\
\text { elementary school level }\end{array}$ & 20 & 11 & 0 & 1 & 3.6 \\
\hline $\begin{array}{l}\text { b. using English as the medium of } \\
\text { instruction in class }\end{array}$ & 11 & 15 & 6 & 0 & 3.2 \\
\hline $\begin{array}{l}\text { c. creating an English environment (e.g. } \\
\text { bilingual Indonesian-English } \\
\text { announcement, signs, billboard) }\end{array}$ & 17 & 15 & 0 & 0 & 3.5 \\
\hline $\begin{array}{l}\text { d. providing more English resources (e.g. } \\
\text { reading books, textbooks, video, etc.) }\end{array}$ & 16 & 16 & 0 & 0 & 3.5 \\
\hline $\begin{array}{l}\text { e. integrating technology and media into } \\
\text { English teaching in class }\end{array}$ & 15 & 17 & 0 & 0 & 3.5 \\
\hline $\begin{array}{l}\text { f. adding more lesson time than 3 } \\
\text { hours/week for English lesson }\end{array}$ & 11 & 21 & 0 & 0 & 3.3 \\
\hline
\end{tabular}




\begin{tabular}{|l|c|c|c|c|c|}
\hline $\begin{array}{l}\text { g. adopting English for Specific Purposes } \\
\text { approach }\end{array}$ & 13 & 19 & 0 & 0 & 3.4 \\
\hline h. teaching pragmatics knowledge & 8 & 24 & 0 & 0 & 3.3 \\
\hline i. teaching Intercultural skill & 8 & 24 & 0 & 0 & 3.3 \\
\hline $\begin{array}{l}\text { j. teaching intercultural communication } \\
\text { strategies }\end{array}$ & 8 & 23 & 1 & 0 & 3.2 \\
\hline $\begin{array}{l}\text { k. introducing varieties of genres } \\
\text { (multimodal texts) often encountered in } \\
\text { the Internet }\end{array}$ & 8 & 23 & 1 & 0 & 3.2 \\
\hline
\end{tabular}

Concerning the teachers' opinions on limited English use domain in most part of Indonesia, they view that this condition provides little opportunity for students to intensively learn, practice and use English for real-life purposes. Moreover, teachers shared their concerns about the short allocation of time for the English lesson at school ( 2 hours per week). This explains the teachers' view on the importance of teaching English from early age at the elementary school level (item A). The limited time of English lesson students received from grade 7 to 12 is considered insufficient in helping learners to learn and acquire English once they graduated from high school. This belief is further reinforced by providing higher exposure (item $\mathrm{C}$ and D), integrating blended learning (item E), and adopting English for Specific Purposes approach (item G). There is also raising awareness on the teaching of pragmatics knowledge and intercultural skill that are in line with their projection of students' future needs in Table 10 (for studying and working abroad). The teachers realize that it is likely for their students in the future to use English in a more interactive nature in such context of studying and working abroad in which pragmatic knowledge and intercultural skill are highly needed.

In the interview, all nine teacher participants described that students need more time and exposure to English in order to catch up with the demand of using English in this globalized world. While remaining faithful to K13, teachers pointed out that 2 hours/week was not enough to provide students opportunities to practice using English in class. As a response to the need for creating an English exposure media at school, the teachers and together with AMINEF ETAs (English Teaching Assistants) organized an English club (an extra-curricular activity) for students who are motivated to upgrade their English knowledge and performance. This English 
club, as the teachers explained, focuses more on English communication skill since this is the skill that the students have little opportunity to do in the classroom.

\section{CONCLUSION}

This study found that there are slightly different perceptions between students in high English exposure areas (SHEE) and those in low English exposure areas. It is understandable that SHEE would have a wider perception on the use of English besides the education sector since the use of English in other sectors (e.g. transnational companies, and tourism sites) is visible in their immediate surroundings. Although they may have to encounter English through the Internet or other media, it is only in the classroom that SLEE experienced exposure to English (through the medium of instruction in Indonesian or a mixture of Indonesian and English). There is also a corresponding result between the students' perception of the use of English and their current needs. Since English is intensively encountered by the students at school, SLEE reported their immediate needs for learning English to pass the National Exam. In contrast, SHEE reported other needs that lean towards the learning of English for communicational purposes (especially through the medium of the Internet). These English needs, however, are still being received from a traditional learning standpoint. Both groups still rank the learning and acquisition of English by focusing on basic language skills and knowledge (grammar and vocabulary). This may not be a surprising result since the focus on English language teaching at school is mostly on these basic skills and knowledge. This result is also quite linear with the teachers' questionnaire results in which they perceived English to have communicative functions in students' social activities in the virtual world.

Students' perceptions of their future English needs also display quite similar results. Both groups seem to be aware of their near future English needs after their high school life. The highest score was assigned to the activities of studying in local/national universities, studying abroad, and working abroad. For these purposes, interestingly, there is a slight change in priorities of learning for both groups. SLEE, who reported earlier to give the highest importance on learning writing (in Question 3: current English needs section), only ranked this skill sixth and promoted speaking-listening skill as their priority, and the inclusion of communication 
strategies as the fifth priority. A similar tendency can also be captured in SHEE response for preferring communication strategies to writing skills.

Interestingly, students and teachers seem to agree on how English should be learned and taught. In general, students (of both groups) realize the need for exposure to a lot of English use through various media (namely, taking extra lessons outside of school, online courses, using English apps, listening and watching English movies, and having foreign friends online). Teachers are also of the opinion that English needs to be taught by providing higher exposure, integrating blended learning, and adopting English for Specific Purposes (ESP) approach. There is also a growing awareness of teaching the pragmatics knowledge and intercultural skill to accommodate the students' future English needs for intercultural communication use. In their effort to providing more opportunities for English use, these teachers organized an English extra-curricular activity, the English Club. The activity is held once a week (90 minutes) in which the teachers focus on developing students' spoken communicative skills.

Despite the results explored in this study, there are a few limitations for future projects to consider. Firstly, the study only surveys nine schools in several contexts in Indonesia with very limited time to conduct classroom observations without interviewing the students. Therefore, it would be more interesting if further studies targeted an individual school in a more holistic manner that includes several classroom observations, students' interviews, and providing a more contextual background of individual school's condition. This holistic approach of studying the school, teachers, students, and the local use of English will provide much deeper insight into the understanding of the local-global attractions and how teachers and students respond to such conditions.

\section{ACKNOWLEDGMENT}

The author would like to thank Universitas Katolik Atma Jaya, Jakarta and AMINEF for funding this project.

\section{REFERENCES}

Buchori, M. (2001). Notes on education in Indonesia. Jakarta: The Jakarta Post.

Canagarajah, A.S. (2005). Reclaiming the local in language policy and practice. New Jersey: Lawrence Erlbaum. 
Canagarajah, A.S. (2006). TESOL at forty: What are the issues?, TESOL Quarterly, 40(1), 934.

Crystal, D. (2003). English as a Global Language (2 ${ }^{\text {nd }}$ edition). Cambridge: Cambridge University Press.

Feak, C.B. (2013). ESP and speaking. In Paltridge, B \& Starfield, S. (Eds.). The handbook of English for Specific Purposes (pp. 137-154). Chichester: John Wiley \& Sons Ltd.

Graddol, D. (1997). The future of English: A guide to forecasting the popularity of the English language in the 21 st century. London: The British Council and The English Company Ltd. Retrieved from https://www.teachingenglish.org.uk/sites/teacheng/files/ pub_learning-elt-future.pdf

Graddol, D. (2006). English next: Why global English may mean the end of 'English as a foreign language'. London: The British Council. Retrieved from https://www.teachingenglish.org.uk/sites/teacheng/files/pub english next.pdf

Hansen-Thomas. H., Richins, L.G., Kakkar, K. and Okeyo, C. (2016). I do not feel I am properly trained to help them! Rural teachers' perceptions of challenges and needs with Englishlanguage learners, Professional Development in Education, 42(2), 308-324.

Hesse-Bibber, S.N. (2010). Mixed methods research: Merging theory with practice. New York: The Guilford Press.

Lawson, S. (2018). English Teaching Assistants in Indonesia: An examination of their intercultural experiences and co-teaching partnerships. An unpublished research report for the Ministry of Research and Technology, Jakarta, Indonesia.

Manara, C. (2014). Intercultural Dialogue on English Language Teaching: Multilingual teacher educator's narrative of professional learning. Newcastle upon Tyne: Cambridge Scholars Publishing.

McKay, S.L. (2002). Teaching English as an International Language. Oxford: Oxford University Press.

Phillipson, R. (1990). Linguistics Imperialism. Oxford: Oxford University Press.

Schneider, E.W. (2011). English around the world: An introduction. Cambridge: Cambridge University Press.

Seidlhofer, B. (2001). Closing a conceptual gap: The case for a description of English as a lingua franca. 